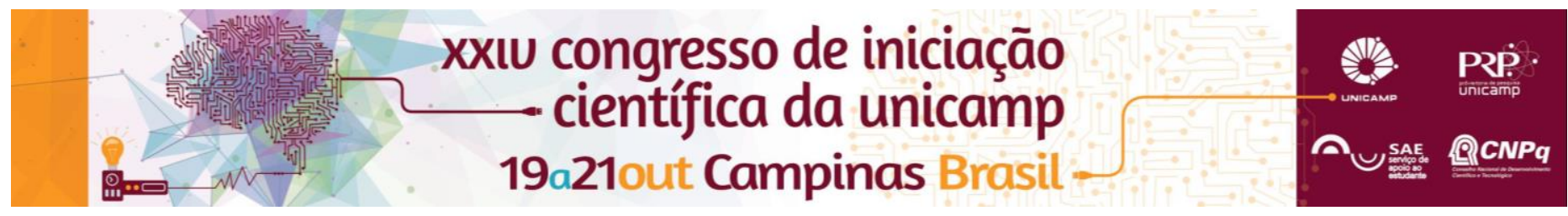

\title{
Gestão de Marketing - Uma análise de como micro e pequenas empresas estão lidando com o assunto
}

\author{
Lucas L. Goulart, Miguel J. Bacic
}

\begin{abstract}
Resumo
Neste trabalho desenvolveu-se e aplicou-se um questionário em algumas empresas com o intuito de avaliar como estas lidavam com o assunto gestão de marketing. O questionário é ordenadoa partir do conceito dos "4 A's" desenvolvido pelo professor Raimar Richers abordando diversos conceitos e ferramentas de gestão de marketing baseando-se, principalmente, nos ensinamentos difundidos por Philip Kotler sobre o assunto. O questionário foi aplicado em empresas de tamanhos e realidas distintas para que fosse possível comparar as respostas de empresas já conceituadas e consolidadas com as respostas das empresas de pequeno porte.
\end{abstract}

\section{Palavras-chave:}

Marketing, Gestão, Empresas

\section{Introdução}

O estudo foi motivo pelo fato de diversos pesquisadores reconhecerem a força existente nas micro e pequenas empresas para a economia de um país no que tange a criação de empregos e desenvolvimento da economia.Segundo o SEBRAE, em 2011 existiam nove milhões de micro e pequenas empresas no Brasil e estas foram responsáveis por $27 \%$ do $\mathrm{PIB}$ do país naquele ano.O interesse pelo desempenho desse segmento na economia do país começou na década de 1980 quando o Brasil passava por uma significativa crise econômica, gerando um grande índice de desemprego.Tendo como base o fato da alta mortalidade das micro e pequenas empresas e da importância do papel econômico que estas apresentam para o país, este trabalho consistiu em realizar um questionário a ser respondido por algumas empresas. O questionário tem como objetivo avaliar a gestão de marketing interna de cada empresa visto que um estudo realizado em 2013 pelo Instituto Brasileiro de Planejamento Tributário, IBPT, apresentou que 41,64\% das causas da mortalidade das MPE's com menos de dois anos deve-se a uma deficiência no conhecimento sobre o mercado e na gestão de marketing interna. Utilizando-se dos estudos do professor Raimar Richer para ordenar o questionário e dos conhecimentos sobre marketing apresentados por Philip Kotler em sua literatura, aplicou-se o questionário via internet para empresas grandes e consolidadas no mercado e em empresas pequenas para poder comparar a gestão de marketing nessas empresas e alavancar diferenças entre essas empresas buscando-se, mais precisamente, aonde as MPE's estão divergindo das grandes.

\section{Resultados e Discussão}

O questionário, realizado com o intuito de comparar a diferença da gestão de marketing entre empresas grande e pequenas contou com 31 respostas sendo que 9 possuem entre 0 e 10 funcionários, 7 possuem entre $11 \mathrm{e}$ 50 funcionários, 2 possuem de 50 a 100 funcionários, 1 de 101 a 250, 3 possuem de 251 a 500 e 9 empresas possuem mais de 1000 funcionários. A pesquisa também abrangeu empresas de diferentes setores como farmacêutico, petrolífero, alimentício, prestação de serviços entre outros sendo que dentro do cenário a respeito do produto produzido pelas empresas tem-se que 16 empresas consideram seu produto na estado de maturidade, em que ocorre uma Constancia no número de vendas, 1 empresa apontou diminuição no número de vendas, estado de declínio, 8 empresas estão com crescimento de vendas, 5 estão no momento de introdução do seu produto no mercado e uma empresa não soube responder a questão.Quanto ao preço praticado pelas empresas, $71 \%$ das que responderam percebem uma diminuição das vendas com o aumento do preço, mas $61 \%$ das empresas que responderam o questionário não possuem nenhum método formal para realizar e registrar essa mudança no mercado.Quanto a precificação dos seus produtos, $67 \%$ considerada os custos envolvidos e os preços vigentes no mercado, sendo o mercado o maior regulador dos preços dos produtos destas empresas, a outra parte, sendo praticamente composta por empresas com até dez funcionários, considera apenas os concorrentes ou em alguns casos considera-se o lucro desejado.Além disso, a estratégia mais utilizada pelas empresas para se diferencia da concorrência são: oferecer uma garantia superior ou igual e fornecer assistência técnica acessível ao cliente, quase metade das empresas tomam como esses dois itens sua estratégia principal para se diferenciar dos concorrentes.

\section{Conclusões}

Considerando-se como pequena empresa, aquelas que possuem até 100 funcionários e as médias e grandes com quantidade superior a este número pode-se perceber que os micro e pequenos empresários não possuem um conhecimento técnico tão grande em marketing, que pode ser provado pela falta de conhecimento em algumas ferramentas abordadas no questionário, além de não possuírem maneiras formais para avaliar o seu desempenho, como indicadores, o que colabora para a dificuldades em indicar o real problema para assim buscar uma solução. Estes fatos demonstram o porque as pesquisar apontam a alta taxa de mortalidade das micro e pequenas empresas, a falta de preparado técnico e de conhecimento no momento em que estão estudando e atuando no negócio.

KOTLER, P.; KELLER, K. Administração de marketing. Trad. Mônica Rosenberg. 12aEd. São Paulo: Prentice Hall, 2006.

O Que é Marketing (Coleção Primeiros Passos, Editora Brasiliense, São Paulo, $1^{\mathrm{a}}$ edição 1981) 